\title{
高周波共振形電力変換関連技術
}

\section{III. 共振形インバータの技術動向}

キーワード

ソフトスイッチング, スイッチング損失, 電磁放射ノイズ

\section{1. まえがき}

電力変換器の比較評価のポイントは, 最近の環境問題ま で考慮すると，次の 4 点にまとめられる。

（1）小ささ（体積・重量） $\rightarrow$ 価格

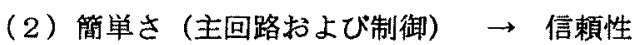

(3) 䪱失の少なさ(変換効率)

（4）優しさ（障害を他に及ぼさないこと）

これらのなかで，（1）上（3）供通し，（2）上（4） は対立することが多い。

本文の課題は, (3) と（4）に絞って各種の共振形イ ンバータに共通する動向を解説することである。ほかの解 説に比べると，本文は斜めから見た感じになる。なお，本 文では個別の共振形インバータの回路構成・動作は説明し ない。共振形インバータの方式には，負荷共振，部分共振， 共振リンク，共振トランジションなどがあるが，これらを 網羅し，しかも，電流形と電圧形を対照しつつ回路構成・ 動作・得失を論じた明快な解説(1)がある。

\section{2. ハードスイッチングからソフトスイッチングヘ}

スイッチ素子の高速化は, 電力変換装置の制御性能の高 度化・小型化を可能にするが，スイッチング損失・サージ 電圧・電磁ノイズなどの問題を䫓在化させる。1 回のスイ ッチングによるエネルギ一損失（単位 J）は高速スイッチを 使え菭減少する。しかし，スイッチング周波数を高くしす ぎるとスイッチング損失（単位W) はむしろ増える。また， 高速スイッチングに伴う急峻な電圧・電流の変化が出力ケ 一ブルに伝わると，4章で述へるように負荷機器端にサ一 ジ電圧を生じたり，電磁放射ノイズを増加させる。

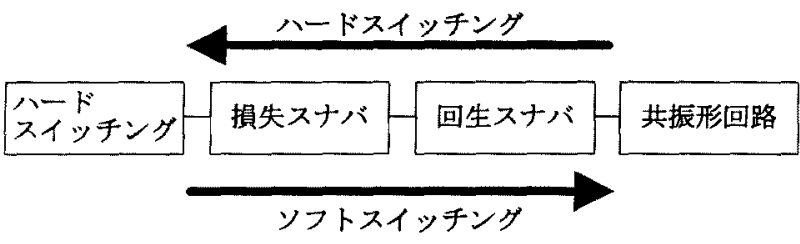

図1 ハードスイッチングから共振回路へ

High-Frequency Switched Resonant Mode Power Conversion Tech. nologies.

111. Trend of Resonant Inverters-High Efficiency and ElectroMagnetic Radiation Noise Reduction-.

By Seiji Kondo, Member (Nagaoka University of Technology).
正員近 藤 正 示 長岡技術科学大学 工学部
オンノオフするときに電压または電流が ○でないと，ス イッチには大きなストレスが加わる。解決策は二つある。 ストレスに耐えられるように大きな定格のスイッチを使う (ハードスイッチング，自己充足型）か，回路を工夫して ストレスを滅少させる(ソフトスイッチング，環境調和型） かである。ハードスイッチングとソフトスイッチングの関 係は，図1のようになる(2)。どれを選ぶかは，前記（1）〜

(4) を総合して判断することになる。

ソフトスイッチングの説明にはZVS と ZCS という用語が よく使われるが，ターンオンノターンオフの区別がされて いない。これらを区別すると，表 1 のようにスイッチング は 4 種類になる。表中の ZVTF，ZVTN などは区別するため の記号である。同表で「電圧＝0」と「電流＝0」には, それぞれ，二通りの意味があり注意が必要である。たとえ ば，第 1 列の「電圧＝0」は，ZVTFではターンオフ後しば らくの間は電圧をＯ近くに保っことを意味するが，ZVTN ではターンオンの前までに電圧を0にすることを意味する。 第 2 列の「電流 $=0 」$ 小，前記と逆にオフ前/オン後にな る。結局，表の ZVTF と ZCTN は事後処理であり，ZVTN と ZCTF は事前処理である。事後処理は，表中に示した簡 单なスナバでよい。一方，事前処理には工夫が必要である。 たとえば，ZVTN では電圧をブロックオフしているスイッ チの電压を○にしてからターンオンしなければならない。 並列Cスナバでいえば，ターンオフのときCに溜まったエ ネルギーを次にターンオンする前に処理しておく必要があ

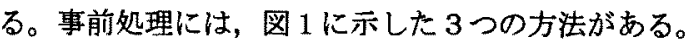

(1) 損失スナバ: エネルギーを抵抗で消費してしまう。

(2) 回生スナバ : エネルギーを直流電源に戻す。

(3) 共振形回路 : エネルギーを主スイッチ近くの相補的に 動作する部分へ移し替える。

表 1 ソフトスイッチングの分類

\begin{tabular}{l|l|l}
\hline & 電任 $=0$ & 電流=0 \\
\cline { 2 - 3 } & ZVS & ZCS \\
\hline ターンオフ & ZVTF & ZCTF \\
(Turn ofF) & 並列Cスナバ & 電流共振形転流 \\
\hline $\begin{array}{l}\text { ターンオン } \\
\text { (Trun oN) }\end{array}$ & ZVTN & ZCTN \\
\hline
\end{tabular}


(2)は直流電源まで含めてゆっくり処理するが必ずしも電圧 を○にはしないのに対して，(3ではスイッチの近くでしか もスイッチングの直前に電圧を○にするという違いがある。

\section{3.共振形インパータで損失は減るか?}

図 2 沖, 補助共振転流ポール形インバータ ${ }^{(10)}$ (図中 ARCP 形と略記。 $L r=25 \mu \mathrm{H}, C r=0.012 \mu \mathrm{F})$ とハードスイッチング形 インバータ (図中 H-SW 形と略記。ARCP 形の共振補助回 路を除いたもの) の損失を筆者らが実測・比較した結果で ある。ともに直流リンク電圧 $280 \mathrm{~V}, 3$ 相 $50 \mathrm{~Hz}$ 出力, $\mathrm{PWM}$ スイッチング周波数 $16 \mathrm{kHz}$ ，主スイッチは IGBT $(600 \mathrm{~V}$, 50A）である。同図から，主スイッチのスイッチング損失は ARCP 形 $W_{S-S W}$ が H-SW 形 $W_{H-S W}$ の約 $1 / 5$ と䫓著に低减して いることがわかる。しかし，ARCP 形の全損失は H-SW 形 に比へてるずかしか低減していない。その理由は，ARCP 形では，補助スイッチのスイッチング椇 $W_{A U X: S W}$ と導通損 $W_{A U X: C O N}$ ，さらに，共振インダクタの導通損 $W_{L r}$ が加算され るためである。これらの低減は今後の課題である。なお, 主スイッチの導通損 $W_{\text {CON }}$ はARCP形とハード形で同じであ る。

以上により，数 kVA 程度の PWM インバータに関する限 りは，ハードスイッチング形自体がすでに高効率であるた め,ARCP 形にしても当初喧伝されたほどには全体の損失は 减らないと考える。

高効辣化のみを目指すならば，複合素子による主スイッ

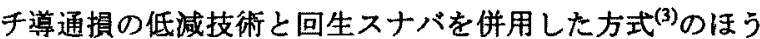
が現時点では優っている。

大容量インバータのスイッチンダ周波数は，ハードスイ ッチングでは高くできないが, ソフトスイッチングならス イッチ以外にもスイッチング損失を分散化できるから高周 波化できる。特に，誘導加热のように一定周波数の高周波

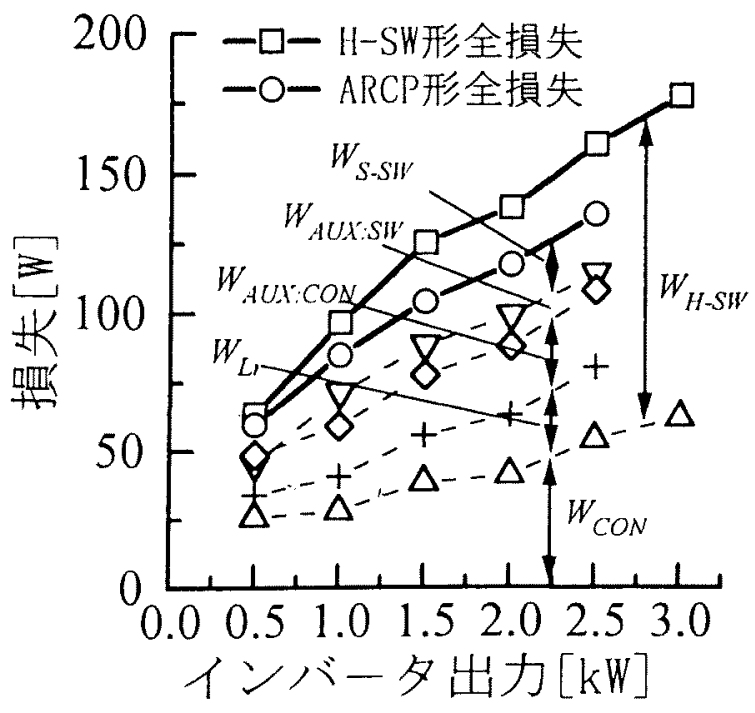

図 2 各インバータの損失とその内訳
出力が必要な応用では，主回路が比較的简単な負荷共振形 インバータを利用できる。

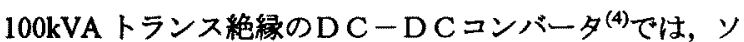
フトスイッチング形のスイッチング周波数はハードスイッ チング形の 4 倍にでき, トランスを軽量化できる。各種の ソフトスイッチング回路方式を比較した結果, 最も效率が 高いものではなく，むしろ主回路・制御の簡単な回路方式 を推奖している。

以上のように，単に損失低減だけでは共振形インバータ の主回路および制御の複雑さを正当化できない。ぜロ電圧 トランジションインバータ (5)のような主回路の簡略化を目 指すか，新たな利点を見出すことが必要と考える。

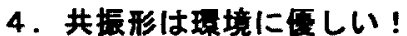

インバータの交流出力端に急峻な電圧・電流の変化が現 れると，各種の問題を引き起こす。たとえば，ハードスイ ッチング形 PWM インバータによる大きな $\mathrm{d} v / \mathrm{d} t$ は電動機の 寿命を短縮する(の，あるいは, 急峻な電圧変化のため電動機 負荷のコモンモード電流が増加し電磁放射ノイズが発生す る(7)。インバータ交流出力の過大な $\mathrm{d} v / \mathrm{d} t$ の規制も検討され $た^{(8)}$ 。

共振形インバータでは，交流出力端の電王変化を抑制で きるため，上記の問題が解消される。

サージ電圧に関しては, $\mathrm{d} v / \mathrm{d} t$ が大きい方形波電圧を配電 ケーブルに加えると, $100 \mathrm{~m}$ 以上先にある負荷端電圧は約 2 倍に跳ね上る。これに比べて，方形波出力共振形インバー 夕を用いて出力電圧の反転時間を $30 \mu \mathrm{s}$ 程度まで長くすれば 配電クーブル負荷端のサージ電圧を抑制できる(9)。

電磁放射ノイズに関しては，補助共振転流ポール形イン

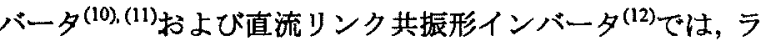
ジオ周波数以上の電磁放射ノイズをハードスイッチング形

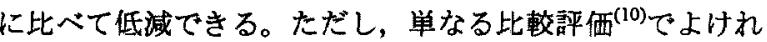
ば試験は容易であるが，CISPR22 などの国際規格に準拠し て評価を行なおうとすると電波暗室 ${ }^{(11)}$ が必要になる。

電磁放射ノイズ低减は，電気自動車では特に重要である。 ドライバがラジオを聞けないことも問題ではあるが，それ だけではない。排気ガスを撒き散らさないため電気自動車 に乗換えるほどのユーザならば，電磁ノイズを撒き散らす ことも嫌うからである。

以上から，障害を外部に出さないという意味での環境と の調和（優しさ, ソフトさ）が，共振形インバータの指向 すべき方向の一つと考える。

\section{5. 受動部品が重要}

共振形インバータでは高周波電力用の受動部品，すなわ ち，インダクタ（以下Lと略記）およびキャパシタ（以下 C と略記）さらには配線方法が，スイッチ素子などの能動 部品よりも重要となる。

共振 Lの導通損は変換効率に大きな影響を与えるから， 低損失化が必要である。筆者らの実験装置ては鉄損をなく 
すため空芯 Lを採用し，銅損低減のためリッツ線を使用し ている。これに対して，磁気ノイズ放射を抑制するために フェライトあるは鉄粉コア入り Lを採用することも考えら れ，鉄損＋銅損の最小化設計法 ${ }^{(13)}$ が参考になる。巻数の多 い空芯Lでは浮遊容量が問題になる ${ }^{(14)}$ 。

共振 Cの低損失化は，それ自身を熱破壊させないために 必要である。100kHz 以上では積層セラミック $\mathrm{C}^{(15)}$ が，それ

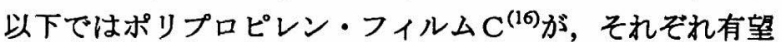
と思われる。

配線インダクタンスの低減は，ハードスイッチング形イ ンバータではスイッチ素子のストレス軽減のために必要で

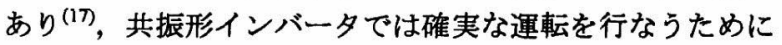
必要である(18)。

配線インダクタンスを低減するため, 正負極 2 枚の銅シ 一トで絶遠物をサンドイッチ状に挟んだ配線材料も考えら れる。その浮遊容量は, 電圧形インバータの直流側クラン プとして有用である。さらに，浮遊容量を積極的に利用す ることも考えられる。たとえば，高周波トランスの巻線間 容量を積極的に利用した L C 複合トランス ${ }^{(19)}$ もつつの有効 な方策である。

\section{6. おわりに}

インバータに限らず，工業製品に対して使用者が要求す ることは，安く，壊れにくく，無駄がなくて，しかも，障 害を外部に及ぼさないことである。全体のバランスが必要 であり, 部分的に極端な高性能化はストレス集中を招きシ ステムを脆弱にする。鉄笳コンクリートは，鉄・セメント・ 砂・石・水の混ざりものであるが，それゆえにこそ強さを 発揮することを考えてみる必要がある。

インバータを構成するスイッチ・キャパシタ・インダク タ・配線は, 決して回路図どおりの理想的なコンポーネン トではない。共振形インバータの原点は, これらの不完全 さをむしろ有用なものとして取り込み，ストレスを分散さ せるようにコンポーネントを組み合わせてシステムを設計 することである。

(平成 8 年 11 月 21 日受付)

\section{文 献}

(1) T. S. Wu, ..., M. Ehsani: A Review of Soft-Switched DC-AC Converters, IEEE IAS'96, pp.1133-1144 (1996.10)

(2) B. K. Bose: Power Electronics and Variable Frequency Drives, IEEE Press, p.118 (1996)
（3）伊東，高橎：トランジスタと IGBT を併用した高勃率インバー 夕，平 7 電気学会産業応用部門全国大会, No.768 (1995.8)

(4) R. L. Steigerwald, R. W. De Doncker, et al.: A Comparison of HighPower DC-DC Soft-Switched Converter Topologies, IEEE Trans. on Ind. App., Vol.32, No.5, pp.1139-1145 (1996.9)

(5) V. Vlatkvic, D. Borojevic, F. C. Lee, et al.: A New Voltage-Transition Three-Phase PWM Rectifier-Inverter Circuits, IEEE PESC'93, pp.868873 (1993)

(6) A. H. Bonnett: Analysis of the Impact of Pulse-Width Modulated Inverter Voltage Waveforms on AC Induction Motors, IEEE Trans. on Ind. App., Vol.32, No.2, pp.386-392 (1996.3)

(7) . S. Ogasawara, H. Ayano, H. Akagi: Measurement and Reduction of EMI Radiated by PWM Inverter-Fed AC Motor Drive System, IEEE IAS'96, pp.1072-1079 (1996.10)

(8) V. R. Stefanovic: Current Development in AC Drives, IPEC-Tokyo'90, pp.382-390 (1990)

（9）近藤，目黒：方形波配電システムの可能性の検討, 電学論 $\mathrm{D}$, Vol.116, No.5, pp.556-562 (1996.5)

(10) 近藤, 南 : 補助共振枟流ポール形インバータにおける電磁放射 ノイズと効率の評価, 電学論 D, Vol.116, No.4, pp.499-500 (1996.4)

(11) 金, 大矢, 深沢 : 部分共振インバータのEM I 評価，平 8 電気 学会産業応用全国大会, No.270 (1996.8)

(12) 稲熊, 大谷, 守屋, 鈴井 : 並列共振形インバー夕電流制御方法 の開発，平 8 電気学会産業応用全国大会，No.57(1996.8)

(13) M. Bartoli, A. Reatti, M. K. Kazimierczuk: Minimum Copper and Core Losses Power Inductor Design, IEEE IAS'96, pp.1369-1376 (1996.10)

(14) G. Grandi, M.K. Kazimierczuk, et al.: Stray Capacitances of SingleLayer Air-Core Inductors for High-Frequency Applications, IEEE IAS'96, pp.1384-1388 (1996.10)

(15) G. Skibinski, J. Pankau: Use of Multi Layer Ceramic (MLC) Capacitors in High Power Converter, IEEE IAS'96, pp.1319-1326 (1996.10)

(16) R. Anderson: Select the Right Plastic Film Capacitor for Your Power Electronic Application, IEEE IAS'96, pp.1327-1330 (1996.10)

(17) D. Braun, R. Lukaszewski, D. Pixler, G. Skibinski: Use of Co-axial CT and Planer Bus to Improve IGBT Device Characterization, IEEE IAS'96, pp.1507-1516 (1996.10)

(18) 佐久閂, 飯田, 松尾: 㭪助共振枟流ポールインバー夕における 配線インダクタンスの影敏, 平8 電気学会産業応用全国大会, No.265 (1996.8)

(19) P. A. J. Rensburg, J. D. van Wyk, J. A. Ferreira: Design and Construction of a Generic Multi-KVA Planer Integrated LCT for a Family of Series Resonant Converters, IEEE IAS'96, pp.1361-1368 (1996.10)

近 蔽 正 示 (正員) 1973 年名古屋大学工学部電子工学科卒業。

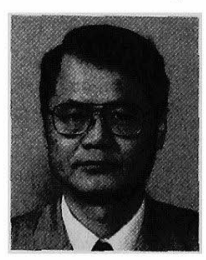
日立製作所を経て, 東京大学生産技術研究所助 手，原島文雄教授の指導のもとに電動機のディ ジタル制御，共振リンク形インバータの研究に 從事。工学博士。1991 年 11 月長岡技術科学大 学助教授, 現在に至る。㭪助共振転流ポール形 インバータ，PMモータの位置センサレス制御， 方形波配電，瞃導機制御系のロバスト化などの 研究に従事。計測自動制御学会, I E E E 会員。 